\title{
TTR
}

Traduction, terminologie, re?daction

\section{Michael Cronin. Translating Ireland. Translation, Languages, Culture. Cork, Cork University Press, 1996, 229 p.}

\section{Donald Bruce}

Volume 9, numéro 1, 1er semestre 1996

Le festin de Babel

Babel's Feast

URI : https://id.erudit.org/iderudit/037251ar

DOI : https://doi.org/10.7202/037251ar

Aller au sommaire du numéro

Éditeur(s)

Association canadienne de traductologie

ISSN

0835-8443 (imprimé)

1708-2188 (numérique)

Découvrir la revue

Citer ce compte rendu

Bruce, D. (1996). Compte rendu de [Michael Cronin. Translating Ireland.

Translation, Languages, Culture. Cork, Cork University Press, 1996, 229 p.] TTR,

9(1), 309-312. https://doi.org/10.7202/037251ar

Tous droits réservés ( $\odot$ TTR: traduction, terminologie, rédaction — Les auteurs, Ce document est protégé par la loi sur le droit d’auteur. L’utilisation des d'utilisation que vous pouvez consulter en ligne.

https://apropos.erudit.org/fr/usagers/politique-dutilisation/ 
Michael Cronin. Translating Ireland. Translation, Languages, Culture. Cork, Cork University Press, 1996, 229 p.

Michael Cronin's book on the history and place of translation in Ireland is an excellent example of some of the more recent work produced by translation scholars. His work resembles that of Eric Cheyfitz, Tejaswini Niranjana, Sherry Simon and others, in that Cronin examines the forms and functions of translation as they have been localized in specific historical circumstances but brings to this historical understanding the conceptual tools of post-modern textual theory, post-colonial theory, gender studies, and information technology. Cronin's study serves the very specific purpose of presenting and analysing the historical development of translation in Ireland from the earliest times to the contemporary period, and at the same time seeks to examine the Anglo-Irish colonial relationship in its linguistic specificity. In this account, translation plays a significant role in the unfolding of Irish cultural history.

Beginning with an 'Outline Chronology of Irish History' and ending with an excellent bibliography and index, Cronin provides the reader with solid tools to undertake the study of "Translation, Languages, Cultures" within the Irish context, as promised in the book's subtitle. In the section on the Middle Ages, 
Cronin takes pains to argue that during this period Ireland was in no way peripheral to England or the Continent ("There is little sense in the medieval period of a beleaguered outpost of Western culture struggling on the edge of darkness."(p. 40)) and details the many activities and contacts established between Ireland and Europe, in part mediated by translation. In addition, he makes clear that Irish language and culture flourished at this time: the vernacular was not suppressed by imperial decree, and the church protected Irish folklore by consigning the native tradition to parchment (pp. 10-11).

The political defeat of the native Irish and the military conquest of the 17th century created a new situation. Earlier translators had translated from Irish into English in order to demonstrate the depth of Irish culture and to refute English propaganda about the 'barbarous Irish'. In the 17th century this attempt at cultural legitimation paradoxically served to undermine Irish and spread the use of English. This century saw the rise of the Ascendancy, the English-speaking landed aristocracy, and translation took on a new role in order to provide this class with a justification to its claim to power and possession: the construction of genealogies from Irish sources contributed to its hegemonic symbolic capital. Throughout the 18th century movements such as the Celtic Revival (1750s and 1760s), Macpherson's apocryphal translations, as well as his claim that the Fenian cycle was actually Scottish in origin created considerable interest in Gaelic. After the act of Union (1800), three major developments greatly affected the Irish: the establishment of a national system of education (Irish was not to be admitted as an examination subject until 1878); the Great Famine of 1845-1847; and, unlike the situation in Québec, the failure of the Catholic Church to actively support and maintain indigenous Irish culture.

Ironically, the romantic Antiquarian movement in Ireland in the nineteenth century worked to undermine the status of the Irish language: translation took on an Orientalist cast and acted as an instrument to recover the past, that is, what was 'already lost'. Notions of decay and loss, crepuscular images and other thematic trappings of the period undermined the value of contemporary Irish: 
for example, the Fenian movement of the 1860 s was more interested in breaking the link with England than in the preservation of the linguistic component of Irish culture. False universalism on the one hand and claims to essentialist untranslatability on the other complicated the picture of rising nationalism in the nineteenth century. However, as the century wore on the Anglo-Irish Ascendancy increasingly felt its 'difference' vis-à-vis the English: Douglas Hyde's translations (1890) of Irish folktales into English "mark a transition from translation as an act of exegesis to translation as an agent of aesthetic and political renewal" (p. 136).

A new irony arose here in that Hyde's translations themselves were more interesting to the readership than the originals upon which they were based. In fact, their publication furthered the project of establishing a national literature in English in Ireland: if some saw it as an incentive to develop a national literature in Irish, writers like Yeats and Singh saw this rather as the beginning of a new literature in English: "thus, the two literatures of modern Ireland can be said to emerge from the translation movement in the nineteenth century." (p. 138)

Cronin pays much attention to the interaction of English and Irish, and to the role of translation in mediating between them: "Is translation an act of pillage and conquest, or is it a bisociative shift towards a newer, more exciting synthesis?" (p. 142) Along with certain other historians, Cronin would argue that the Anglo-Irish dialect used by Singh revitalised the inert cliches of the source language and in so doing reinvigorated English.

In the 1920s and 1930s the Irish state undertook to translate foreign works into Irish in order to establish a base of texts in the language. Irish independence saw immense activity in translation, on all levels and in all discourses: "Joyce's activity parallelled the intense translation ferment in Ireland at the beginning of the twentieth century. Two national literatures would emerge from the ceaseless movement between languages, a birth that would have been literally and figuratively inconceivable without the long gestation of translation." (p. 161) In Cronin's analysis, the 
subsequent integration of Ireland into the European Community has had a positive and stimulating effect: "It is noteworthy that it was the move towards European integration and the incorporation of Ireland into a transnational, multilingual European culture that prompted the moves towards the defence of Irish cultural specificity in translation." (p. 174)

Cronin covers all the bases in that, if only briefly, he also examines the role of gender in translation: he describes and analyses the work of Charlotte Brooke, quoting from the gender-conscious Preface to her translation, the Reliques of Irish Poetry (1789), to indicate not only her self-consciousness as a female translator in this period, but also her romantic vision of translation as a conciliatory practice between the English and the Irish peoples (p. 100). Elsewhere, near the end of his book, Cronin similarly discusses the use of telecommunications technology in bringing Irish translators closer in from the periphery of the other EEC nations, curiously enough re-enacting links which had been forged long ago in medieval times.

An interesting feature is that throughout his text Cronin quotes directly from Irish texts, but provides translations for the reader: this gives Irish a textual, material reality which might have simply been abstracted had it been subsumed by English.

The value of Cronin's contribution is threefold: first, he has produced a work of scholarship which fills a gap in the history of translation; second, he has analysed cultural interchange, linguistic evolution and the birth of an important modern literature in terms of the role played by translation; and three, he has written an interesting book of high quality which is of value not only to those interested in the history and culture of Ireland, but also to readers who are seeking to understand cultural change, alterity, identity, and interaction in the light of contemporary thinking about these matters. The book is well worth reading.

Donald Bruce University of Alberta 